Article

\title{
Exergetic Aspects of Hydrogen Energy Systems-The Case Study of a Fuel Cell Bus
}

\author{
Evanthia A. Nanaki * and Christopher J. Koroneos \\ Department of Mechanical Engineering, University of Western Macedonia, Bakola and Salviera, Kozani 50100, \\ Greece; koroneos@aix.meng.auth.gr \\ * Correspondence: evananaki@gmail.com
}

Academic Editor: Arnulf Jäger-Waldau

Received: 1 October 2016; Accepted: 10 February 2017; Published: 15 February 2017

\begin{abstract}
Electrifying transportation is a promising approach to alleviate climate change issues arising from increased emissions. This study examines a system for the production of hydrogen using renewable energy sources as well as its use in buses. The electricity requirements for the production of hydrogen through the electrolysis of water, are covered by renewable energy sources. Fuel cells are being used to utilize hydrogen to power the bus. Exergy analysis for the system is carried out. Based on a steady-state model of the processes, exergy efficiencies are calculated for all subsystems. The subsystems with the highest proportion of irreversibility are identified and compared. It is shown that PV panel has exergetic efficiency of $12.74 \%$, wind turbine of $45 \%$, electrolysis of $67 \%$, and fuel cells of $40 \%$.
\end{abstract}

Keywords: exergy analysis; fuel cell bus; hydrogen; sustainable transportation

\section{Introduction}

Road transport energy supply mainly depends on fossil fuels, the use of which is responsible for climate change emissions, such as $\mathrm{CO}_{2}, \mathrm{SO}_{2}, \mathrm{NO}_{\mathrm{x}}$, and other particulate matters. To be more specific, the transportation sector accounts for approximately one-fifth of global primary energy use and one quarter of all energy relates carbon dioxide $\left(\mathrm{CO}_{2}\right)$ emissions with nearly half of those emissions originating from passenger vehicles [1]. Improving road transport requires taking into consideration not only the environmental issues, but also the economic challenges that may arise due to possible oil price hikes and supply disruptions. In this direction, various efforts are being undertaken in order to achieve a decarbonized, energy secured road transport system. The introduction of alternative transport fuels and vehicles can be a viable solution for a low-carbon transportation system. In this study, the alternative powertrain technology of hydrogen is considered capable of delivering a sustainable road transport system with near-zero emissions [2]. It has been shown that electric vehicles have less air pollution cost and human health impacts compared to conventional gasoline vehicles. The economic cost of emissions and human health impact reduction potential can be up to $45 \%$ and $35 \%$, respectively, if electric vehicles are charged through solar charging stations.

The use of hydrogen constitutes an attractive alternative to fossil fuels as it can be produced both from renewable (hydro, wind, solar, biomass, geothermal) and non-renewable (coal, natural gas, nuclear) energy sources. Hydrogen can then be utilized in high-efficiency power generation systems, including fuel cells, for both vehicular transportation and distributed electricity generation. At present, electrolysis is the technology of choice for converting renewable electricity into hydrogen. Furthermore, the usage of hydrogen can not only play a significant role in the reduction of energy-related $\mathrm{CO}_{2}$ emissions, but also it can contribute to limiting global temperature rise to $2{ }^{\circ} \mathrm{C}$ [3]. In this direction, a large number of countries are setting specific targets for the deployment of fuel cell and hydrogen technologies in the transportation sector. For instance, the European roadmap for the development and 
deployment of hydrogen and fuel cell technologies has set a target of 0.4-1.8 million hydrogen vehicles sold per year by 2020 [4]. A shift towards a low carbon transportation system, taking into consideration issues such as energy security and emissions reduction, is placed on the agenda of many European cities and regions, which have committed to initiate change in their public transport systems $[5,6]$.

The environmental burdens-in terms of $\mathrm{CO}_{2}, \mathrm{CO}, \mathrm{HC}, \mathrm{PM}, \mathrm{NO}_{\mathrm{x}}$ emissions-have been calculated for the diesel and CNG bus fleets of nine European cities [7]. The results of this study indicate that in order for public transportation to reach zero local emissions the deployment of electric powertrains is necessary. The use of hydrogen in the public transportation sector, when produced from $100 \%$ renewable energy sources, results in the operation of public transportation vehicles, with zero $\mathrm{CO}_{2}$ emissions along the entire hydrogen value chain [8,9]. The environmental benefits of fuel cell technology [10] indicate that a long-term transition strategy to a hydrogen economy can decrease costs and improve performance of fuel cell buses.

Fuel cell (FC) buses are built on a conventional chassis and contain a fuel cell system and an electric battery which form the heart of the powertrain. Fueled by hydrogen, they emit only water vapor. A fuel cell system typically consists of auxiliary components (humidifier, pumps, valves, etc., grouped together as the balance of the plant) and a fuel cell stack which is made up of bipolar plates and membrane electrode assemblies. Hydrogen buses are electric buses that feature a longer lifetime and lower maintenance costs than diesel buses in the long-term, as abrasion is expected to be lower. Different technical solutions exist for the main architecture of the FC bus powertrain. It can comprise fuel cell stacks as a direct energy source for propulsion in combination with super-capacitors and different sizes of batteries as energy storage.

The production of hydrogen from renewable energy sources has been studied in the literature by various authors. Lodhi [11] has analyzed the high temperature water dissociation, thermochemical water splitting, water electrolysis, and photolysis. Lodhi [12] also classified solar, sea/ocean, hydro, wind, and nuclear energy as green primary sources to produce hydrogen. Lemus and Duart [13] assessed the cost and distribution of hydrogen production and transportation. Alstrum-Acevedo et al. [14] presented the production of hydrogen by mimicking photosynthesis reactions. Tanksale et al. [15] reviewed the catalytic production methods of hydrogen from biomass (i.e., gasification, pyrolysis, and sugar conversion).

The tool of exergy analysis is used in the present study to evaluate the energetic performance of an energy system for the production of hydrogen and its use in buses. The use of the exergy analysis can overcome the limitations of a simple energy analysis as it allows the evaluation of the thermodynamic performance of the energy system under study and the determination of the energy quality disintegration during energy transfer and conversion [16]. In addition, exergy constitutes a more easily understood thermodynamic property—compared to entropy-to represent irreversibilities in complex systems [17]. Exergy, which is derived from the second law of thermodynamics, can help identify the irreversibilities associated with the energy flow and its conversion. The exergy analysis allows the evaluation of the maximum available work in terms of quality and quantity for a critical assessment of the thermodynamic performance of any energy producing system; it has been widely used in the design, simulation, and performance evaluation of energy systems [18-20]. The method of exergy analysis has been accepted as a sound method for the interpretation of the axiomatic role of the second law in the design and optimization of energy systems in terms of both efficiency and cost, and as a supplementary tool to aid in decision-making about the parameters and criteria that may lead to optimality in terms of the impact of engineering systems to the environment [21-24]. Finally, given the qualitative relationship between exergy and sustainability [25], exergy can be a useful tool in handling energy planning and decision-making for sustainable development.

The main goal of this paper is to discuss the role of hydrogen and fuel cell systems for a sustainable future, and present a case study on the exergy analysis of fuel cell vehicles from energy, and sustainability points of views. The role of exergy in performance assessment and sustainability achievement is also discussed. The focus of this study is to investigate the use of clean technology 
features for public transportation, with the aim to reduce greenhouse gas emissions (GHG) and also improve vehicle performance. The objective of this paper is to elaborate the proposed renewable energy system for fueling different types of vehicles in geographical locations with a Mediterranean climate (or islands). The paper is structured as follows: Sections 2 and 3 describe the system configuration, data, variables, and methodology used. Section 4 presents the main results. Finally, Sections 5 includes the conclusions.

\section{Materials and Methods}

Exergy is defined as the amount of work available from an energy source. Exergy is the useful energy that can be exploited from an energy resource or a material, which is subjected in an approximately reversible procedure, from an initial situation until balance with the natural environment is restored. Exergy is dependent on the relative situation of a system and its ambient conditions, as they are determined by a sum of parameters, which can be equal to zero (in a balanced situation with the environment) [21]. Exergy is a measurement of how far a certain system deviates from a state of equilibrium with its environment. The exergy concept incorporates both the quantitative and qualitative properties of energy. Every irreversible phenomenon causes exergy losses leading to exergy destruction of the process, or to an increased consumption of energy from whatever source the energy was derived.

The objective of exergy analysis is to determine the exergy losses (thermodynamic imperfections) and to evaluate, quantitatively, the causes of the thermodynamic imperfection of the process under consideration. Exergy analysis can lead to all types of thermodynamic improvement of the process under consideration [21]. It is noted that the main advantage of exergy analysis is that it connects the real output with the theoretical (ideal) one. Even if the theoretical maximum cannot be reached, it provides a point of comparison for the further possibilities of a procedure optimization. The hydrogen production system under study is assumed to operate in a steady state. For a steady state system the mass balance equation can be expressed by Equation (1):

$$
\sum m_{\text {in }}=\sum m_{\text {out }}
$$

where, $m$ is the mass flow rate, and the subscript in stands for inlet and out for outlet. The general energy balance is expressed by Equation (2):

$$
\sum E_{\text {in }}=\sum E_{\text {out }}
$$

where $E_{\text {in }}$ is the rate of net energy transfer in, $E_{\text {out }}$ is the rate of net energy transfer out by heat, work and mass; $Q=Q_{\text {net }}$ is the rate of net heat input, $W=W_{\text {net }}$ is the rate of net work output, and $h$ is the specific enthalpy [26].

$$
\begin{aligned}
E_{k i n, \text { in }}+E_{\text {pot, in }}+ & \text { (eventual other forms of energy })+Q+\sum m_{\text {in }} h_{\text {in }} \\
& =E_{\text {kin, in }+} E_{\text {pot, } \text { in }+}(\text { eventual other forms of energy })+W+\sum m_{\text {out }}, h_{\text {out }}
\end{aligned}
$$

Given that in the system under study the changes in kinetic and potential energy are negligible, Equation (3) can be written as follows:

$$
Q+\sum_{m_{\text {in }} h_{\text {in }}}=W+\sum_{m_{\text {out }} h_{\text {out }}}
$$

This equation expresses that the total amount of energy input of the system is equal to the total amount of energy output. The energy efficiency of the system is expressed by Equation (5):

$$
n_{i}=\frac{\sum E_{\text {out }}}{\sum E_{\text {in }}}
$$


The exergy of the system is expressed by the following equations:

$$
\sum E_{X_{\text {in }}}-\sum E_{X_{\text {out }}}=\sum E_{X_{\text {dest }}}
$$

or

$$
\sum\left(\left(1-\frac{T_{O}}{T_{K}}\right) Q_{k}-W\right)+\sum m_{\text {in }}\left(e x_{t m, \text { in }}+e x_{c h, \text { in }}\right)-\sum m_{\text {out }}\left(e x_{t m, \text { out }}+e x_{c h, o u t}\right)=\sum E_{X}{ }_{\text {dest }}
$$

with:

$$
e x_{t m}=\left(h-h_{0}\right)-T_{0}\left(S-S_{0}\right)
$$

where $Q_{k}$ is the heat transfer rate through the boundary at temperature $T_{k}$ at location $k, W$ is the work rate, $e x_{t m}$ is the thermo-mechanical flow of exergy, $s$ is the specific entropy, and the subscript zero indicates properties at the temperature and pressure of the environment of the system considered—standard state [27]. Equation (8) can be expanded to the form of Equation (9):

$$
e x_{t m}=\left(h-h_{0}\right)-\left(T_{0} S-T_{0} S_{0}\right)
$$

The term $T_{0} S-T_{0} S_{0}$ represents the exergy that has been destroyed and it is presented as $E_{X d e s t}$. The standard chemical exergy of gaseous reference species can, therefore, be expressed by the form of Equation (10) [20]:

$$
E_{c h, i}=m_{i} R T_{0} \ln \frac{P_{0}}{P_{k}}
$$

where, $R$ is the specific gas constant. Different ways of formulating exergetic efficiency proposed in the literature have been given in detail elsewhere [28]. The exergetic efficiency expresses all exergy input as used exergy, and all exergy output as useful exergy. Therefore, the exergetic efficiency is expressed by Equation (11):

$$
n_{i i}=n_{e x}=\frac{E_{X_{\text {out }}}}{E_{X_{\text {in }}}}
$$

The efficiency will be improved to the maximum when the exergy loss or irreversibility $E_{\text {Xin }}-E_{\text {Xout }}$ is minimized [29]. When heat at a temperature $T_{t}>T_{0}$ is available and the temperature of a thermodynamic system is $T_{t}$ and the temperature of the environment is $T_{0}$ its exergy quality can be expressed by the quality factor (Equation (12)):

$$
\text { Quality factor }=1-\frac{T_{O}}{T_{t}}
$$

When the temperature $T_{t}$, at which the heat is available, increases, the quality factor increases, too. The irreversibility or the exergy loss of an open system in steady state is given by:

$$
I=\sum_{i}\left(1-\frac{T_{o}}{T_{i}}\right) Q_{i}-W_{\text {net }}+\sum_{\text {in }}(m e)_{\text {in }}-\sum_{\text {out }}(m e)_{\text {out }}
$$

where $T$ is the temperature of environment, $Q_{i}$ it is the heat transportation rate through the system boundaries for a constant temperature $T_{i}, W_{\text {net }}$ is the rate of work production, $m$ is the mass flowrate of every flow of materials that enters the system and e is the specific exergy of the flows. The specific exergy $e$ constitutes of thermo mechanical, $e_{t m}$ and chemical $e_{c h}$ exergy. Exergy analysis is employed to detect and to evaluate quantitatively the causes of thermodynamic imperfection of the process under consideration. Exergy analysis indicates the possibilities of thermodynamic improvement of the process under consideration [30-34]. 


\section{System Configuration}

The system under study includes a hydrogen production installation-via water electrolysis-using renewable energy sources, so as to use it in a fuel cell bus (FC). Figure 1 illustrates the system configuration. The renewable PV and wind power are taken as primary energy sources. It is noted that solar PV and wind systems cannot provide a continuous supply due to the fact that those systems will generate electricity only during sunny and windy days. Hence, a combination of these two sources improves the overall energy output. A proper optimization is required to ensure having an optimal number and size of PV and WT. All of the energy systems are connected in parallel to a common DC bus line through appropriate power electronic interfacing circuits. When there is an excess solar generation available, the electrolyzer is activated to initiate the necessary hydrogen production for bus fueling, which is delivered to hydrogen storage tanks at low pressures.

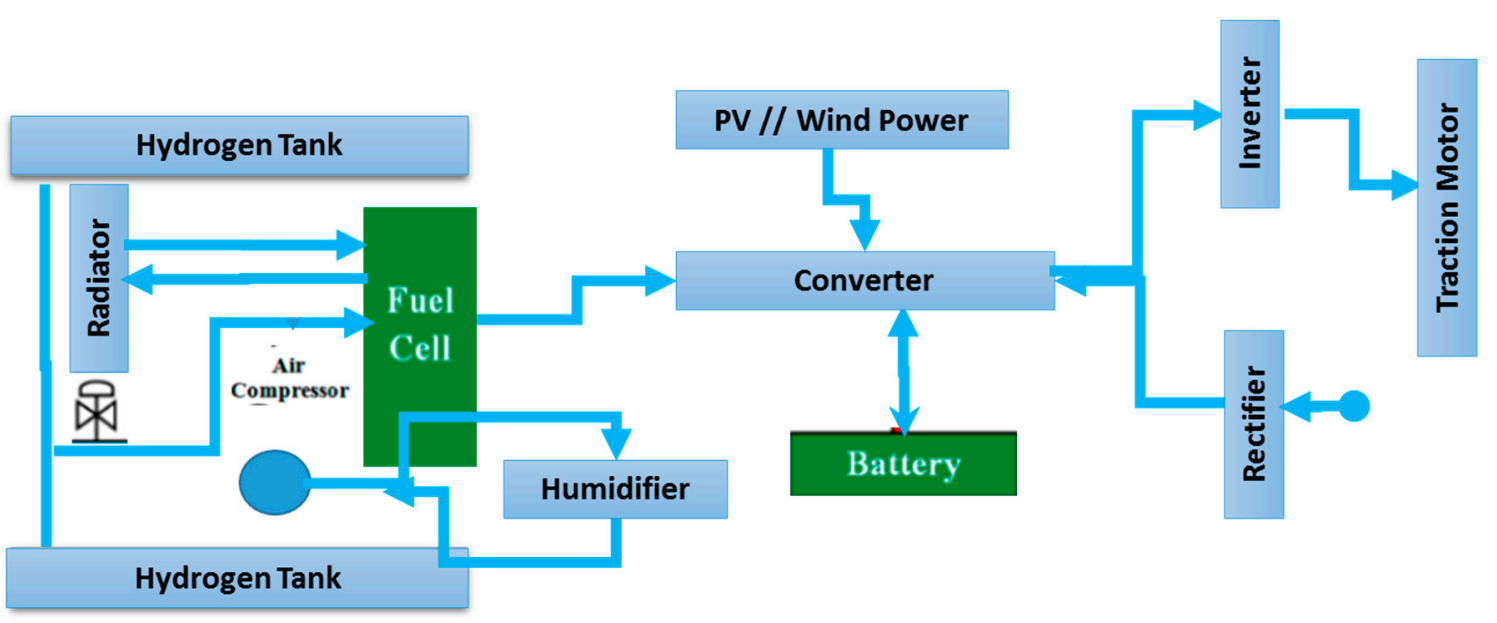

Figure 1. System configuration.

Solar and wind energy are converted to electricity via a PV non-tracking flat plate collector and a wind turbine. The study employs a Siemens PV SM 50/12 V collector and a $100 \mathrm{~kW}$ Lorax wind turbine. Table 1 summarizes the technical characteristics of the PV collector; whereas Table 2 shows the technical characteristics of the wind turbine. The daily demand for $\mathrm{H}_{2}$ production reaches $2390 \mathrm{kWh}$, out of which $2210 \mathrm{kWh}$ covers the energy demand of electrolysis and $180 \mathrm{kWh}$ the energy demand of compression. In order to achieve the 3600 psi compression, a three-phase compressor was used. Table 3 summarizes the technical specifications of the compressor.

Table 1. PV's technical specifications [35].

\begin{tabular}{cc}
\hline Type & SIEMENS SM 50/12 V-Siemens Solar Gmbh \\
\hline Nominal voltage & $12 \mathrm{~V}$ \\
Technology & Multicrystalline Si POWERMAX TOPS \\
Voltage at the maximum power point $\left(25^{\circ} \mathrm{C}\right)$ & $16.60 \mathrm{~V}$ \\
Maximum voltage (open circuit) $\left(25^{\circ} \mathrm{C}\right)$ & $21.4 \mathrm{~V}$ \\
Current at the maximum power point & $3.05 \mathrm{~A}$ \\
Maximum current (short circuit output) & $3.4 \mathrm{~A}$ \\
Length/Width/Depth & $1293 \times 329 \times 34 \mathrm{~mm}$ \\
Weight & $5.5 \mathrm{Kg}$ \\
\hline
\end{tabular}


Table 2. Wind turbine's technical specifications [36].

\begin{tabular}{|c|c|}
\hline Rotor Diameter & $21 \mathrm{~m}$ \\
\hline Rated power output & $100 \mathrm{~kW}$ \\
\hline Rotor's blades & 3 rotor blades type LM 9.7 \\
\hline Maximum wind speed & $67.0 \mathrm{~m} / \mathrm{s}$ \\
\hline Gearbox & 2-stage spur/planetary with a ratio of 1:33 manufacturer by Dorstener \\
\hline Generator & Asynchronous type manufactured by Weier/Elin. \\
\hline Steel tube tower & 35/38 m; manufactured by Fuhrländer/AWN/ESTA \\
\hline Rotor sweep & $346 \mathrm{M} 2$ \\
\hline
\end{tabular}

Table 3. Compressor's technical specifications.

\begin{tabular}{cc}
\hline Hydrogen Flow & 2000 SCFH \\
\hline Input pressure & $100 \mathrm{psi}$ \\
Outlet pressure & $3600 \mathrm{psi}$ \\
Number of phases & 3 \\
Weight & $3600 \mathrm{~kg}$ \\
Volume & $6000 \mathrm{~L}$ \\
Water cooling flow & 20 gpm at $30 \mathrm{C}$ \\
Electric power & $20,000 \mathrm{~W}$ \\
\hline
\end{tabular}

A bus fuel cell is made up, in general, of a fuel cell stack system, an air compressor system, a hydrogen supply system and an air refrigeration system. The fuel cell stack system generates the required power for the bus (Figure 2a,b). The air compression sub-system provides the essential oxygen, through air, to the fuel cells. The system contains two compressor stages, compression and hyper-compression, which are been driven by the air of evaporation of the fuel cell, an air to air exchanger, and the filters. The hydrogen supply system provides fuel cells with $\mathrm{H}_{2}$ and it is made up of a storage tank, a hydrogen injector, the filters and the dehydrators. It should be mentioned that the fuel cell reaction does not consume all of the hydrogen provided. The unconsumed hydrogen exits the fuel cells mixed with the produced water and then it is recovered for future usage. The refrigeration system removes the produced heat of the fuel cell reaction and liquefies the air and hydrogen input. The refrigeration subsystem contains by a refrigerator, a water pump, a refrigerator fan, a deionizer filter, and a liquid collection container.

The bus considered in this study uses a fuel cell engine from XCELLSiS Fuel Cell Engines, which is a consortium of Daimler-Chrysler, Ford Motor Company and Ballard Power Systems [37]. Table 4 illustrates the technical characteristics of the engine. The hydrogen fuel cell converts hydrogen and oxygen directly into electricity, water, and waste heat, while producing none of the noxious by-products typical of the combustion processes. A single fuel cell is connected in series with other cells in a stack to provide a higher voltage. A basic hydrogen fuel cell power system is comprised of this stack together with the required ancillary components to provide the stack with the necessary reactants, as well as to remove the wastes.

Table 4. Technical characteristics of XCELLSiS fuel cell engine [37].

\begin{tabular}{cc}
\hline Fuel Cell Technology & PEM \\
\hline Engine Model & XCELLSiS XCS-HY-205 \\
Volume/Weight of the engine & $5.32 \mathrm{~m}^{3} / 2170 \mathrm{~kg}$ \\
Power to shaft/Maximum Torsion & $205 \mathrm{~kW}$ at $2100 \mathrm{rpm} / 1100 \mathrm{Nm}$ at $800 \mathrm{rpm}$ \\
Efficiency & $44 \%$ to $37 \%$ (Lower Thermogenic Power) \\
Fuel & Air Hydrogen 3600 psig \\
Fuel restore system/Capacity & Restore cylinders of pressured gas $/ 17,500$ SCFH or $460.5 \mathrm{Nm}^{3}$ \\
Bus' Autonomy & Approximately 225 miles \\
Air supply system/Maximum Air Flow & Two level compressor $/ 600$ SCFM \\
\hline
\end{tabular}




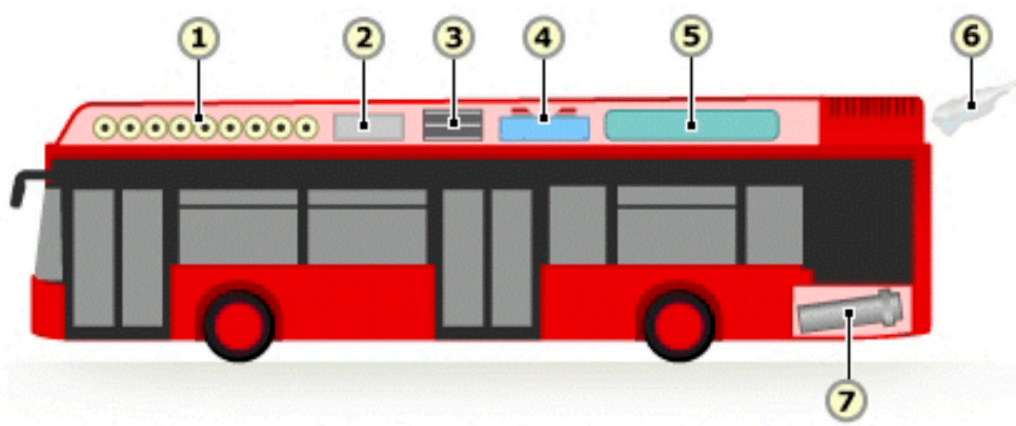

(a)

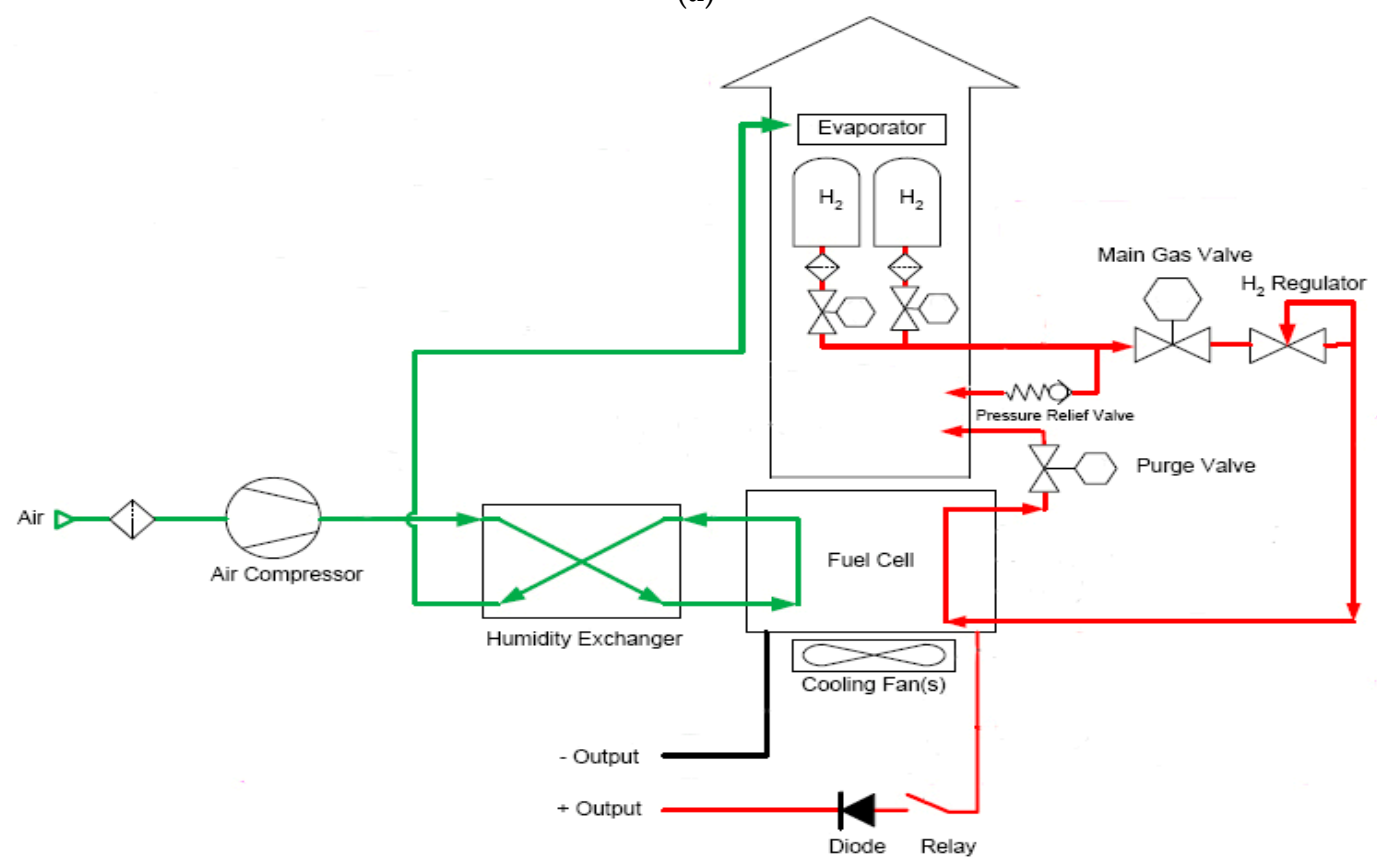

(b)

Figure 2. (a) Simple configuration of a fuel cell bus; and (b) configuration of the fuel cell system [37]. 1. Hydrogen storage; 2 . fuel cell supply unit; 3 . fuel cell stacks; 4 . fuel cell cooling units; 5 . air conditioning unit; 6 . water vapor from exhausts; 7 . electric motor.

The production of hydrogen, for fueling the FC bus, is made by a high-pressure catalyst [38]. Table 5, summarizes the technical characteristics of the electrolyte. Daily hydrogen requirements for fueling the FC bus reach $17,500 \mathrm{SCF}$ or $460.5 \mathrm{Nm}^{3} /$ day $\left(1 \mathrm{Nm}^{3}=38 \mathrm{SCF}\right)$. Based on data of Table 4 it is estimated that $7.7 \mathrm{~h}$ and $287 \mathrm{~kW}$ or $2210 \mathrm{Kwh} /$ day are required for covering the daily hydrogen demand.

Table 5. Technical specifications of the high pressure electrolyte [39].

\begin{tabular}{cc}
\hline Model of Electrolyte & No 60 \\
\hline Production of $\mathrm{H}_{2}$ & $60\left(\mathrm{Nm}^{3} / \mathrm{h}\right)$ \\
Outlet Pressure of $\mathrm{H}_{2}$ & $16(\mathrm{Bar})$ \\
Hydrogen purity & $99.8 \%$ \\
Oxygen purity & $99.2 \%$ \\
Power consumption & $4.8\left(\mathrm{kWh} / \mathrm{Nm}^{3}\right)$ \\
Power DC A/V & $3000 / 100$ \\
Consumption of water during operation & $1 \mathrm{~L} / \mathrm{Nm}^{3}$ \\
Hydrogen purity after treatment & $99.9998 \%$ \\
\hline
\end{tabular}




\section{Results-Exergy Analysis}

Based on the analysis presented on Section 2 exergy analysis is carried out for the primary energy sources, the production system as well as for the bus fuel cell.

\subsection{Exergy Analysis of Primary Energy Sources}

The exergy analysis of the photovoltaic panel uses data of a sustainability analysis [40]. Based on our previous study [30] the overall exergy efficiency of the photovoltaic panel using multicrystalline $\mathrm{Si}$ solar cells is considered to be $12.74 \%$. As far as the wind turbine is concerned, the kinetic energy of moving air is converted to electricity. The efficiency of the wind turbine depends on its type, on the rotor diameter, and on the wind speed. Figure 3 indicates that the ratio of the change of the produced power to the initial power not only depends on the nominal power of the turbine, but also on the wind speed change.

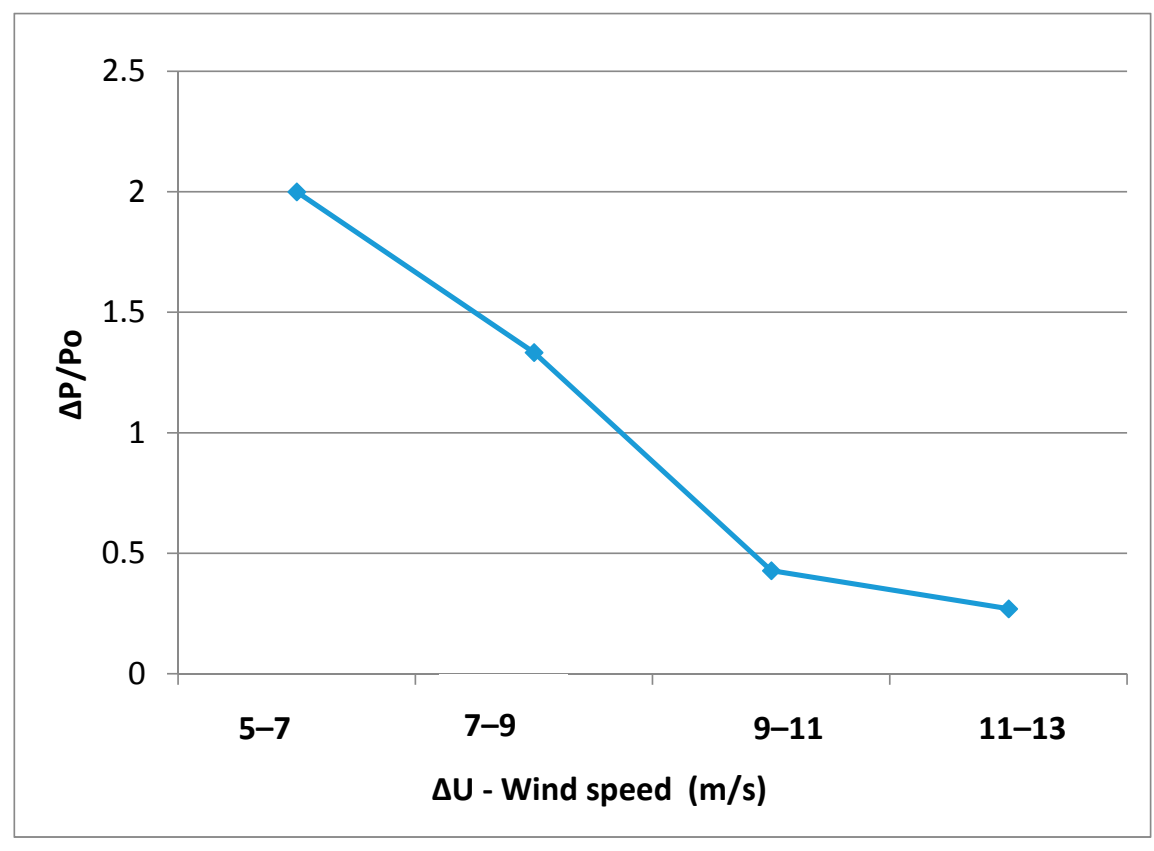

Figure 3. Power change to the initial power, in relation to the wind speed change.

Table 6 indicates that the change of the ratio of the produced power to the initial power, in relation to the wind speed change, depends on the wind speed range in which the turbine works. However, if the surface of the rotor is taken into account, the results are modified in that the turbine with a larger rotor diameter shows a worse behavior as the wind speed changes. Utilization of the wind's potential (the ratio of the produced power of the wind turbine per square meter of rotor, to the energy density of the wind per square meter) in relation to the wind speed (Figure 3) increases at low wind speed values and is almost stabilized at wind speeds greater than $7 \mathrm{~m} / \mathrm{s}$.

Table 6. Power produced $(\mathrm{kW})$ by wind turbine under examination from different wind speeds.

\begin{tabular}{cc}
\hline Wind Speed $(\mathrm{m} / \mathbf{s})$ & Output $(\mathbf{k W})$ \\
\hline 5 & 10 \\
7 & 30 \\
9 & 70 \\
11 & 100 \\
13 & 127 \\
\hline
\end{tabular}


Figures 4 and 5 indicate that wind turbines cannot take advantage of the total power of the wind. According to Betz's law, wind turbines can take advantage of up to $60 \%$ of the power of the wind. Nevertheless, in practice, their efficiency is about $40 \%$ for quite high wind speeds. The rest of the energy density of the wind not obtainable is exergy loss. This exergy loss appears mainly as heat. It is attributed to the friction between the rotor shaft and the bearings, the heat that the cooling fluid abducts from the gearbox, and the heat that the cooling fluid of the generator abducts from it and the thyristors, which assist in smooth starting of the turbine and which lose $1 \%-2 \%$ of the energy that passes through them. Taking into consideration above data, exergy efficiency is equal to $45 \%$.

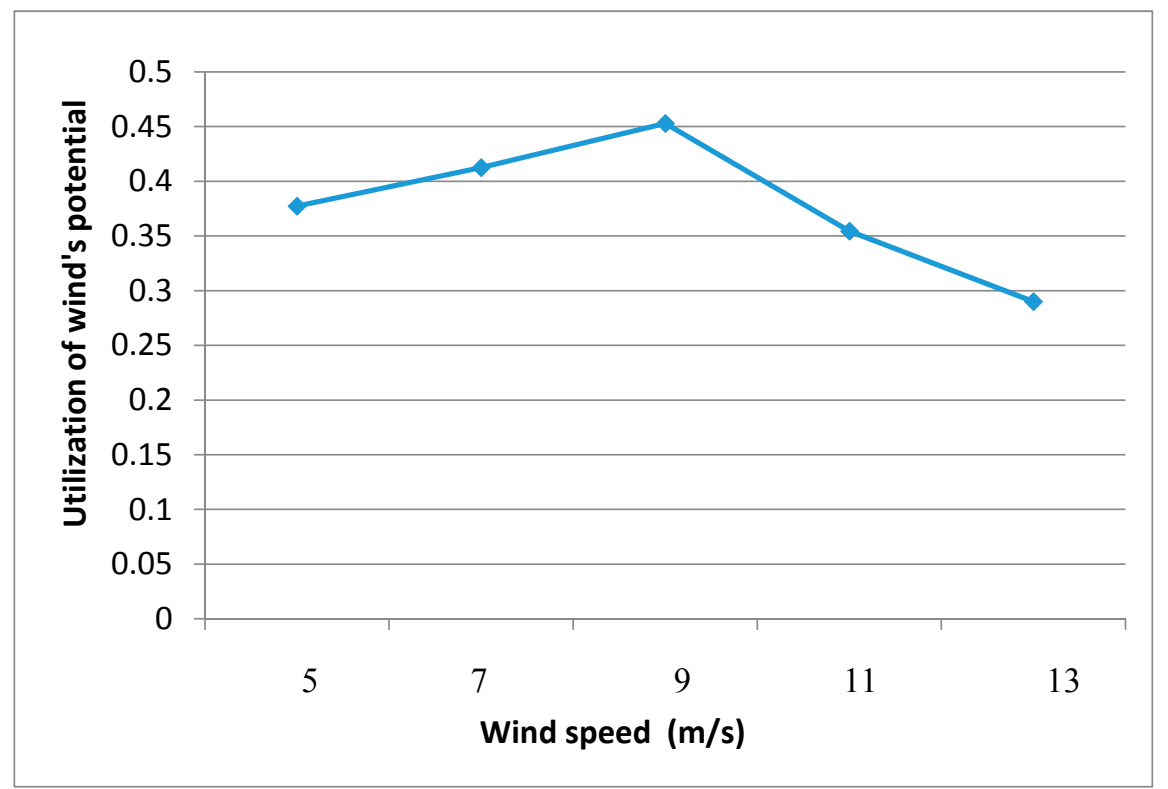

Figure 4. Utilization of the wind's potential in relation to the wind speed.

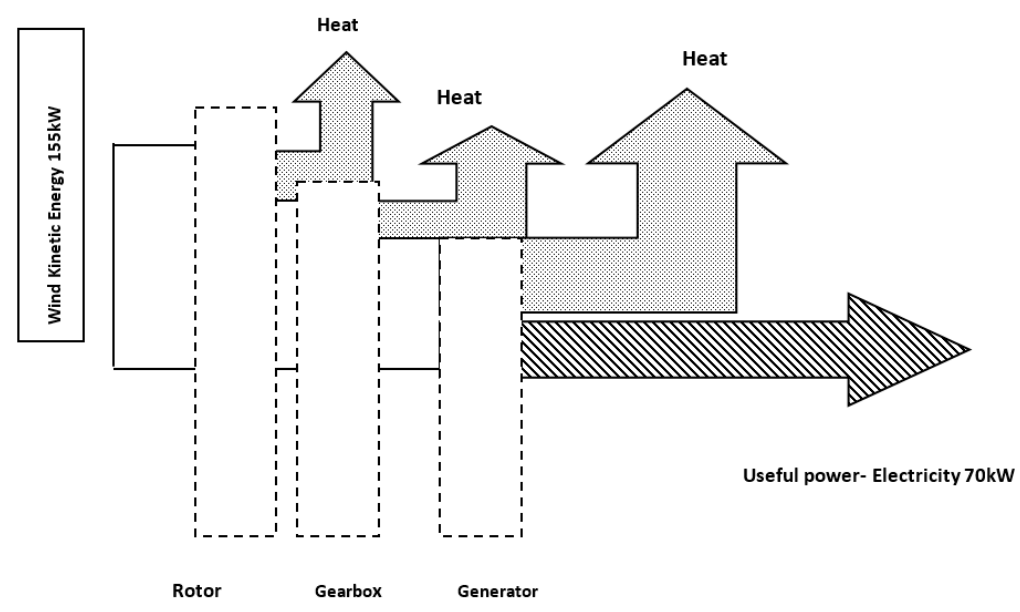

Figure 5. Exergy losses for the different components of the wind turbine.

\subsection{Exergy Analysis of the Production System}

Electrolysis is a hydrogen production process that can be described through the following catalytic reaction:

$$
2 \mathrm{H}_{2} \mathrm{O} \rightarrow 2 \mathrm{H}_{2}+\mathrm{O}_{2}(\mathrm{R} 1)
$$

Power is provided by electricity produced from the photovoltaic panel. The total energy requirements for electrolysis are the heat produced by the hydrogen combustion and the electricity 
from the Gibbs free energy change. In an ideal case, additional heat is added in order to counterbalance the minimal electric energy and the total energy requirements. In practice, due to irreversibilities in the cell, there is enough heat produced to overlap the difference. Exergy analysis of the production system includes the following:

- Electrolysis of water, including the cleaning and the pumping of water. The temperature and the pressure of the outlet gases of the electrolysis are $359 \mathrm{~K}$ and $0.101 \mathrm{MPa}$, respectively.

- Cleaning of hydrogen. The flow of hydrogen is at $308 \mathrm{~K}$ and the condensed humidity is recycled.

- Cleaning of oxygen, same as hydrogen.

- Compression of hydrogen. The hydrogen is compressed to $24 \mathrm{MPa}$ through a three-stage compressor at $308 \mathrm{~K}$. The condensed humidity is recycled.

The electrolysis system flowchart is presented in Figure 6 and the data of the system in Table 7. The analysis uses formal data of thermodynamic attributes and values of basic enthalpy and chemical exergy. Basic enthalpy equals the difference of the generation enthalpy of a substance and the components' enthalpy at a given temperature.

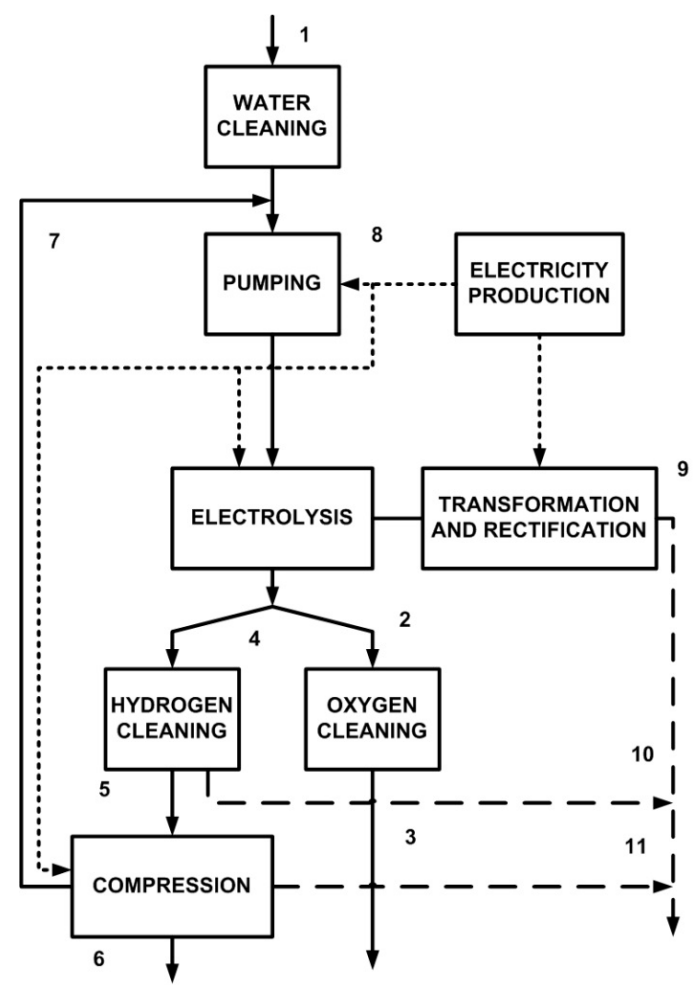

Figure 6. Electrolysis system flowchart. The flows of mass appear with straight line, the electric flows with dotted lines, and the flows of heat with interrupting lines [41].

Table 8 summarizes the results of exergy analysis; whereas Figure 7 illustrates the exergy losses throughout the electrolysis system. Energy (and exergy) efficiency values (Table 7) for the overall considered process (Figure 6) are determined by dividing the energy (exergy) output in the products by the total energy (exergy) input, and multiplying by $100 \%$. The flow values of energy and exergy have been normalized by dividing the value with the total energy input and multiplying it by 100 . Thus, the normalized values are the values that we would calculate if, in the entry, we had energy equivalent to 100 (in corresponding units). The ratio of the inlet to the outlet of energy or exergy of the system is the energy or exergy efficiency. In this case the energy efficiency is $77 \%$ and the exergy efficiency is $67 \%$. 
Table 7. Data referring to the flows of Figure 2 [41].

\begin{tabular}{|c|c|c|c|c|c|c|}
\hline \multirow{2}{*}{$\mathbf{a} / \mathbf{a}$} & \multicolumn{3}{|c|}{ Mass Flow (kg/s) } & \multirow{2}{*}{$\begin{array}{c}\text { Temperature } \\
\text { (K) }\end{array}$} & \multirow{2}{*}{$\begin{array}{c}\text { Pressure } \\
\text { (MPa) }\end{array}$} & \multirow{2}{*}{$\begin{array}{c}\text { Energy Flow } \\
\text { (MW) }\end{array}$} \\
\hline & $\mathrm{H}_{2} \mathrm{O}$ & $\mathbf{H}_{2}$ & $\mathrm{O}_{2}$ & & & \\
\hline \multicolumn{7}{|c|}{ Mass Flow } \\
\hline 1 & 61.1 & 0 & 0 & 298 & 0.101 & - \\
\hline 2 & 11.6 & 0 & 53 & 359 & 0.101 & - \\
\hline 3 & 1.7 & 0 & 53 & 308 & 0.101 & - \\
\hline 4 & 33.2 & 6.69 & 0 & 359 & 0.101 & - \\
\hline 5 & 3.5 & 6.69 & 0 & 308 & 0.101 & - \\
\hline 6 & 0.025 & 6.69 & 0 & 308 & 22 & - \\
\hline 7 & 48.1 & 0 & 0 & 298 & 0.101 & - \\
\hline \multicolumn{7}{|c|}{ Electricity and Heat Flow } \\
\hline 8 & & & & & & 60 \\
\hline 9 & & & & 315 & & 56 \\
\hline 10 & & & & 315 & & 113 \\
\hline 11 & & & & 315 & & 22 \\
\hline
\end{tabular}

Table 8. Energy and exergy efficiency throughout the stages of the system (from [41]).

\begin{tabular}{ccc}
\hline Stage & Energy Efficiency & Exergy Efficiency \\
\hline Hydrogen Cleaning & $\mathbf{9 1 . 6}$ & 98.9 \\
Hydrogen Compression & $\mathbf{9 3 . 2}$ & 97.5 \\
Electrolysis & $\mathbf{1 0 0}$ & 72.5 \\
Oxygen Cleaning & 25 & 54.5 \\
\hline
\end{tabular}

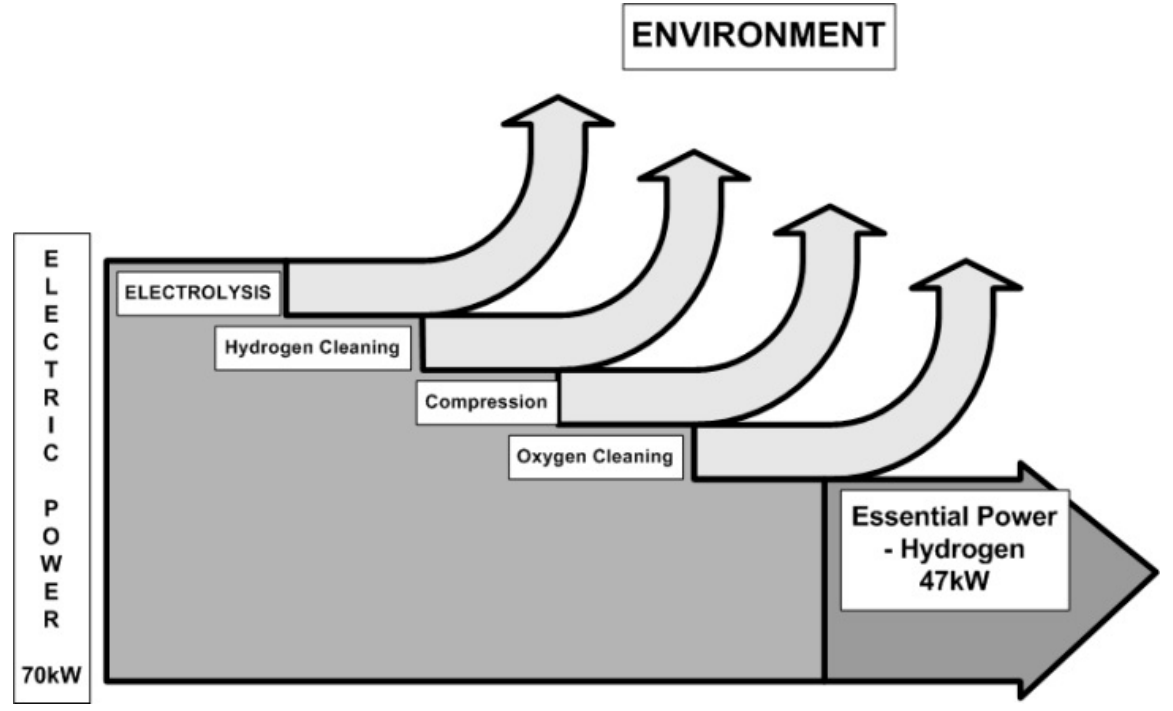

Figure 7. Exergy losses throughout the electrolysis system.

\subsection{Exergy Analysis of the Fuel Cell System}

The fuel cell system consists of the fuel cell stacks and several subsystems that manage the fuel (hydrogen), oxidant (oxygen), water, power, heat, and other factors that affect the performance of the fuel cell stack (i.e., air compressor, hydrogen injector, as well as the refrigerator). Each subsystem supports the vital functions of the fuel cell stack, such as the fuel delivery, air supply, water and thermal management, and power conditioning. The assumptions and conditions of the model used in the exergy analysis are listed as follows:

- The fuel cell system functions at a constant temperature of $75^{\circ} \mathrm{C}$. 
- The amount of hydrogen used is double the theoretical amount needed, while the $\mathrm{O}_{2}$ use is 1.75 times more than the theoretical amount needed.

- Environment pressure is at $1 \mathrm{Atm}$, environment temperature is $298.15 \mathrm{~K}$ and air is made up of $79 \% \mathrm{~N}$ and $21 \% \mathrm{O}_{2}$.

- The storage tank of hydrogen has steady pressure of $205 \mathrm{Atm}$ and temperature of $298 \mathrm{~K}$ conditions.

- There is heat exchange between the environment and the fuel cells, the refrigerator, and the compressor. Twenty percent of the produced heat is considered as thermal loss, while the rest is removed by the refrigerator.

- The heat exchange between the refrigerator and the environment reachs $60^{\circ} \mathrm{C}$ and the temperature of the heat exchange is the temperature of the compressor.

- The pressure of the fuel cells is in a linear junction with the electric current density-from $1.3 \mathrm{Atm}$ at $0.11 \mathrm{amp} / \mathrm{cm}^{2}$ until $3 \mathrm{Atm}$ at $1.08 \mathrm{amp} / \mathrm{cm}^{2}$.

The simulation of the fuel cell stack used in this work is a Ballard fuel cell with an active surface of $232 \mathrm{~cm}^{2}$ and a membrane developed by DuPont. The total voltage produced by the fuel cell stack results by multiplying the voltage of one fuel cell with the number of the fuel cells in the stack. In the current application the stack is made up of 40 fuel cells. The modelling of the system takes into account each element, the thermodynamic, and chemical relations, while the isentropic efficiency is based on empiric data provided by Ballard Co.

Energy analysis provides the loads of all the various elements of the system, "parasitic loads", such as the air compressor load, the pump load, and the fan load. The power of the system is equal to the stack power $\left(W_{\text {gross }}-i v\right)$ minus the sum of "parasitic loads" (Equation (14)):

$$
W_{\text {net }}=W_{\text {cross }}-i v-W_{a c}-W_{\text {pump }}-W_{\text {fan }}
$$

Taken into consideration is the fact that the exergy of the air is zero and the chemical exergy of the hydrogen is $235.2 \mathrm{~kJ} / \mathrm{mol}$; the exergy efficiency of the system is expressed as:

$$
\psi_{\text {sys }}=\frac{W_{\text {net }}}{m_{\mathrm{H}_{2} \text { cons }} m_{\mathrm{H}_{2} \text { cons }}\left(\left(\varepsilon_{\mathrm{H}_{2}}\right)_{\text {in }}\right)_{\text {sys }}}
$$

Based on Equation (13) and the above assumptions the irreversibility of the fuel cell as well as of the air compressor are calculated. The irreversibility of the super-compressor is calculated considering that the heat exchange between the super-compressor and the environment is zero. Furthermore, the irreversibility of the air to air heat exchanger, of hydrogen injector-for minimum heat exchange-as well as the irreversibility of the refrigerator are calculated.

The results indicate that the exergy efficiencies for this system vary from $32.3 \%$ to $53 \%$ at the current density of 0.054 to $1.29 \mathrm{amp} / \mathrm{cm}^{2}$, respectively. The exergy efficiency of the fuel cell as a function of the current density is illustrated in Figure 8. It is noted that the exergy efficiency decreases with increasing current density. This can be attributed to the reactants' flow rates and hydrogen pressure. The reactants' flow rates increase depending on the increasing load. However, hydrogen pressure decreases when output current increases. In addition, it is noticed that below a current density of $0.054 \mathrm{Amp} / \mathrm{cm}^{2}$ exergy efficiency drops rapidly to zero as the fuel cell is unable to provide the energy required to drive the ancillary components. Thus, at very low current densities, the efficiencies are driven downward by the parasitic load of the ancillary components, while at high current densities, they are gradually reduced by Ohmic losses in the fuel cell. Based on the above the overall exergy efficiency is calculated as $40 \%$-assuming that the bus operates with constant speed and the fuel cells produces constant electric current density. 


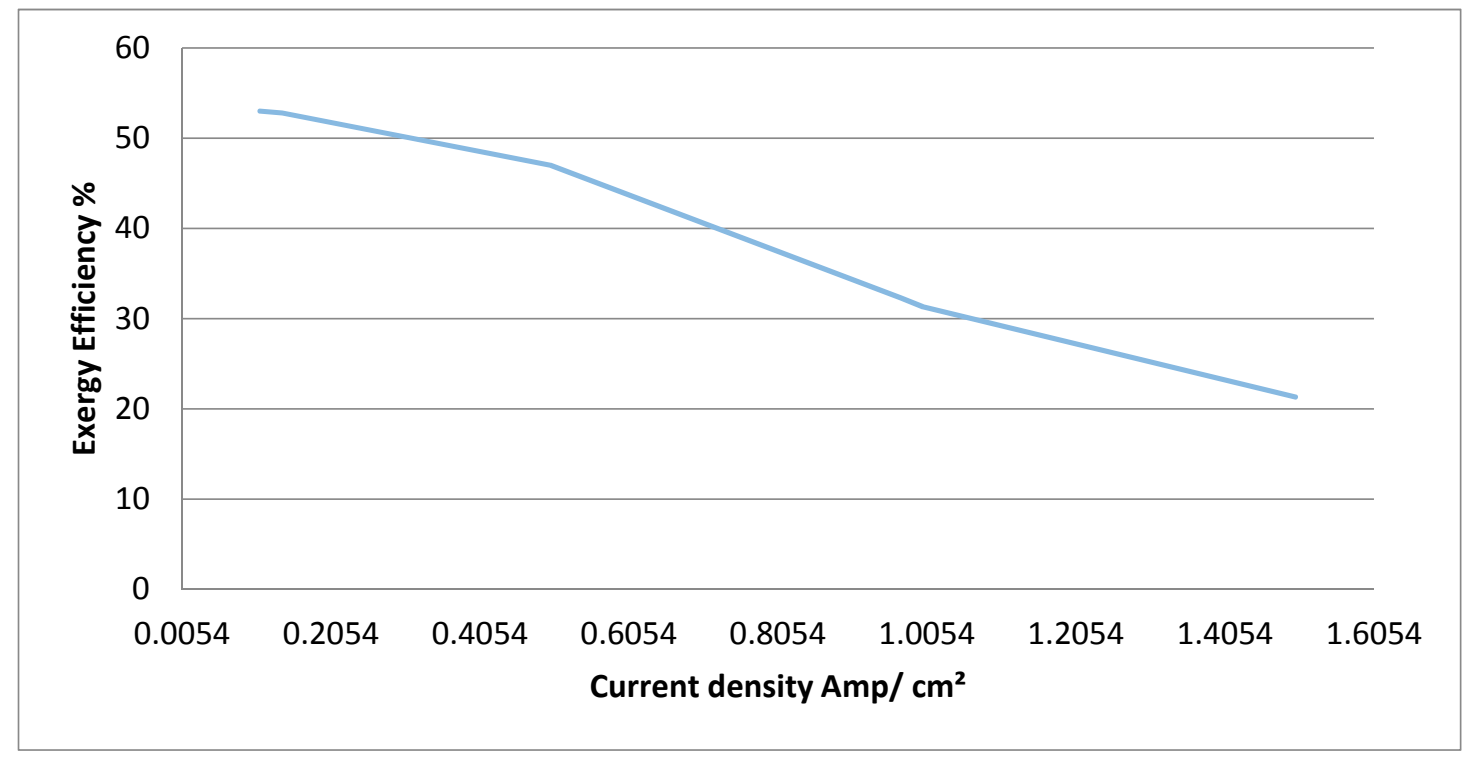

Figure 8. Exergy efficiency of fuel cell system.

\section{Discussion and Conclusions}

Taking into consideration the fact that hydrogen and fuel cells can be considered as a significant alternative energy source for future sustainable transportation systems, the development of hydrogen production and fuel cell technologies is going to play a significant role in creating a sustainable transportation energy future. A hydrogen energy system, suitable for transportation, has been examined in this study. The hydrogen required to drive the fuel cell stack is produced by renewable energy sources (wind and solar energy).

An exergy analysis for the abovementioned system has been carried out in order to evaluate the system's exergy efficiency. The exergy losses are attributed to the irreversibilities of the system under examination. From the results, it can be seen that some of the subsystems appear to have high efficiencies (Figure 9). In other cases, like the conversion of solar energy to electricity, the efficiencies are lower, in order to meet the electricity needs of the system. Exergy analysis indicated that there should be a decrease of the internal losses. It is noted that the exhaust heat has very small exergy content; for example, the exergy content of the exhaust heat from the engine of bus, does not have the essential exergy for the heating of its cabin. The refrigeration water is responsible for a small percent of the exergy losses, which are basically caused by the electrolysis process itself. It should also be noted that as the PV modules employed in this study, do not reflect the state of the art, significant improvement in the efficiency of the PV system should be expected-given that best in class modules today are well above $20 \%$ conversion efficiency.

All of the input energy and exergy to the process is associated with the driving input for each case. The byproduct oxygen contains small quantities of energy and exergy. Most of the output energy is associated with used cooling water and hydrogen, and most of the output exergy with the hydrogen. From the abovementioned it can be suggested that exergy analyses indicate that the products are more valuable. Additionally, in order to reduce losses, exergy analyses indicate that internal consumptions must be reduced.

In this direction, the results suggest that substantial improvements can be made in the performance of the fuel cell system. The irreversibilities noticed in the fuel cell, could be reduced primarily by reducing the activation and Ohmic overpotentials. This study points out the importance of the exergy analysis of hydrogen energy systems that are used in transportation. All of the input energy and exergy to the process is associated with the driving input for each case. The byproduct oxygen contains small quantities of energy and exergy. Most of the output energy is associated with used cooling 
water and hydrogen, and most of the output exergy with the hydrogen. This observation can often be generalized to other fuel-production processes. That is, products of fuel-production processes often have high energy and exergy contents, and wastes often have high energy and low exergy contents. Thus, energy analyses often indicate that wastes are more valuable than products, while exergy analyses indicate that products are more valuable. Additionally, to reduce losses, energy analyses often indicate that quantities of waste effluents must be reduced, while exergy analyses indicate that internal consumptions must be reduced.

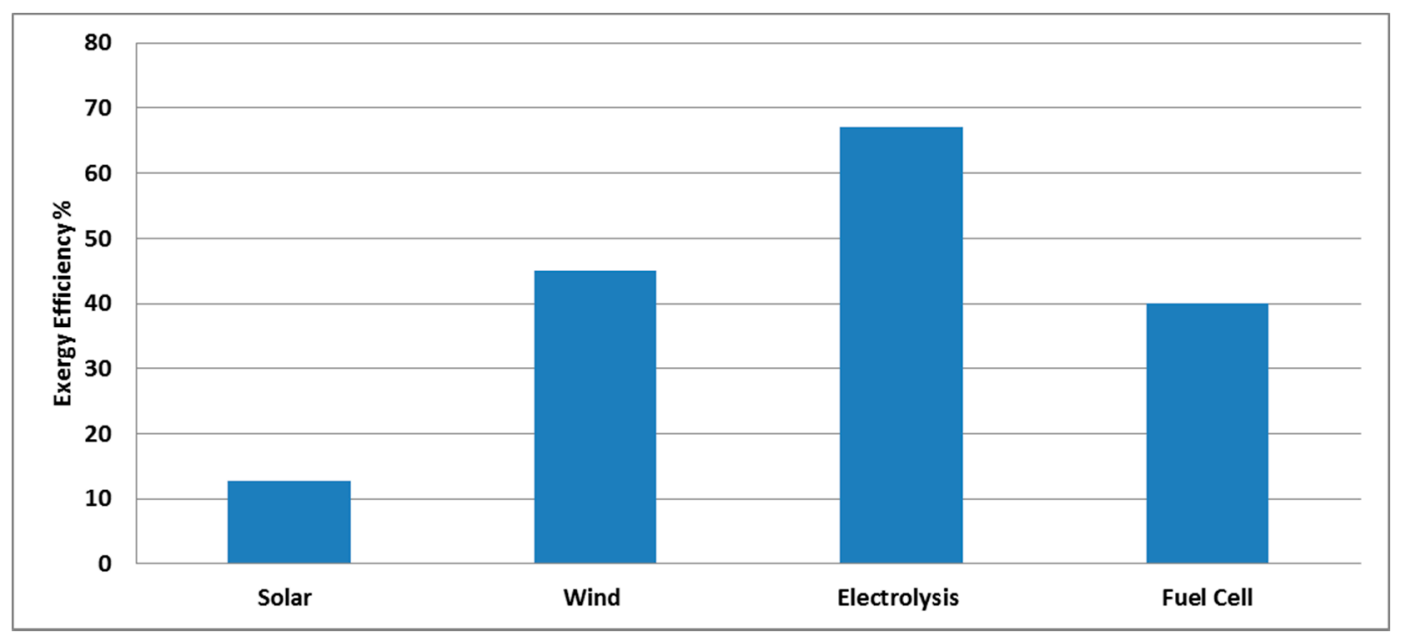

Figure 9. Exergy efficiencies of different subsystems of hydrogen energy system.

Exergy analysis is an effective method using the conservation of mass and conservation of energy principles together with the second law of thermodynamics, which can be employed for the design and analysis of hydrogen energy systems. It is an efficient technique revealing whether or not, and by how much, it is possible to design more efficient energy systems by reducing the inefficiencies in existing systems.

Figure 10 illustrates system's exergy losses. The exergy losses represent the exergy destructed not the available exergy in the system. The exergy losses analysis shows that $37 \%$ of the exergy destruction takes place in PV panel, $23 \%$ in wind turbine, $14 \%$ in electrolysis, and $26 \%$ in fuel cell. A significant advantage from the usage of renewable energy systems in hydrogen energy systems is that they are environmentally friendly, since they emit very few dangerous pollutants. On the other hand, their main disadvantage lies in their incapability to take advantage of a large part of the available energy. This is balanced by the fact that RES are inexhaustible. Compared to the results of Rosen [41], who thermodynamically compared hydrocarbon-based processes, such as steam methane reforming and coal gasification, non-hydrocarbon-based and integrated SMR linked to the non-hydrocarbon-based process, it is seen that exergy efficiency in hydrocarbon-based processes changes from $19 \%$ to $83 \%$, whereas in the system under study exergy efficiencies are between $12.74 \%-67 \%$.

Finally, in regards to the cost of a fuel cell electric bus, it is noted that the capital pricing has significantly decreased since the first deployments in the 1990s. Since the first deployments in the 1990s, purchasing costs for fuel cell electric buses have fallen significantly by more than $75 \%$ [42]. Additionally, many funding opportunities enable the deployment of fuel cell buses on a larger scale. As per Ballard's estimations [43], the price of a 12-m fuel cell electric bus-without subsidy—could be below $€ 500,000$ by 2020 . Further analysis is required in order to assess the economic, as well as the environmental, aspects of this system. 


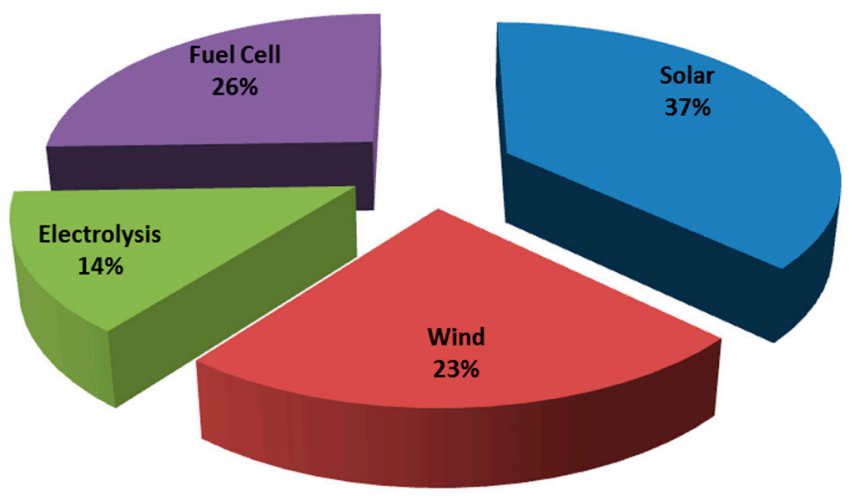

Figure 10. Exergy destruction as a percentage of the total exergy destroyed for different systems of the hydrogen energy system under examination.

Author Contributions: Christopher J. Koroneos and Evanthia A. Nanaki conceived the idea; Evanthia A. Nanaki analyzed the data; Christopher J. Koroneos contributed materials/analysis tools; Evanthia A. Nanaki wrote the paper.

Conflicts of Interest: The authors declare no conflict of interest.

\section{Abbreviations}

$Q$

$m$

$h$

COP

Ex

$T$

$S$

$w$

$R$

$C_{P}$

$\eta$

I

Heat transfer rate $(\mathrm{kW})$

Mass flow rates $(\mathrm{kg} / \mathrm{s})$

Specific enthalpy $(\mathrm{kJ} / \mathrm{kg})$

Coefficient of Performance

Exergy Rate $(\mathrm{Kw})$

Temperature (K)

Specific entropy $(\mathrm{kJ} / \mathrm{kgK})$

Specific work $(\mathrm{kJ} / \mathrm{kg})$

Specific gas constant $(\mathrm{kJ} / \mathrm{kgK})$

Specific Heat Value (kJ/kgK)

Efficiency (\%)

Exergy loss (kW)

\section{References}

1. Organisation for Economic Co-operation and Development; International Energy Agency. Energy Technology Perspectives 2010; International Energy Agency: Paris, France, 2010; Available online: http://www.iea.org (accessed on 9 February 2017).

2. International Energy Agency. IEA Renewable Energy Essentials: Wind; International Energy Agency: Paris, France, 2008.

3. Organisation for Economic Co-operation and Development; International Energy Agency. Technology Roadmap. Hydrogen and Fuel Cells; International Energy Agency: Paris, France, 2015.

4. European Hydrogen and Fuel Cell Technology Platform. 2005. Available online: www.hfpeurope.org/hfp/ keydocs (accessed on 9 February 2017).

5. European Council. European Council Conclusions on the 2030 Climate and Energy Policy Framework (23 and 24 October 2014); European Council: Brussels, Belgium, 2014.

6. C40 Clean Bus Declaration. Available online: http://newsroom.unfccc.int/lpaa/transport/c40-clean-busdeclaration-technology-and-finance-for-clean-urban-transport/ (accessed on 9 February 2017).

7. Nanaki, E.A.; Koroneos, C.J.; Roset, J.; Suscac, T.H.; Christensen, T.H.; Hurtado, S.D.; Rybka, A.; Kopitovic, J.; Heidrich, O.; López-Jiménez, P.A. Environmental assessment of 9 European public bus transportation systems. J. Sustain. Cities Soc. 2017, 28, 42-52. [CrossRef] 
8. Balat, M.; Balat, M. Political, economic and environmental impacts of biomass-based hydrogen. Int. J. Hydrog. Energy 2009, 34, 3589-3603. [CrossRef]

9. Balla, M.; Wietschelb, M. The future of hydrogen-Opportunities and challenges. Int. J. Hydrog. Energy 2009, 34, 615-627. [CrossRef]

10. Karlstrom, M. Local environmental benefits of fuel cell buses-A case study. J. Clean. Prod. 2005, 13, 679-685. [CrossRef]

11. Lodhi, M.A.K. Hydrogen production from renewable sources of Energy. Int. J. Hydrogen. Energy 1987, 12, 461-468. [CrossRef]

12. Lodhi, M.A.K. Helio-hydro and helio-thermal production of hydrogen. Int. J. Hydrogen. Energy 2004, 29, 1099-1113. [CrossRef]

13. Lemus, R.G.; Duart, J.M.M. Updated hydrogen production costs and parities for conventional and renewable technologies. Int. J. Hydrogen. Energy 2010, 35, 3929-3936. [CrossRef]

14. Alstrum-Acevedo, J.H.; Brennaman, M.K.; Meyer, T.J. Chemical approaches to artificial photosynthesis. 2. Inorg. Chem. 2005, 44, 6802-6827. [CrossRef] [PubMed]

15. Tanksale, A.; Beltramini, J.N.; Lu, G.M. A review of catalytic hydrogen production methods from biomass. Renew. Sustain. Energy Rev. 2010, 14, 166-182. [CrossRef]

16. Sui, X.; Zhang, Y.; Shao, S.; Zhang, S. Exergetic life cycle assessment of cement production process with waste heat power generation. Energy Convers. Manag. 2014, 88, 684-692. [CrossRef]

17. Hammond, G.P.; Winnett, A.B. The Influence of Thermodynamic Ideas on Ecological Economics: An Interdisciplinary Critique. Sustainability 2009, 1, 1195-1225. [CrossRef]

18. Cownden, R.; Nahon, M.; Rosen, M.A. Exergy analysis of a fuel cell power system for transportation applications. Exergy 2001, 1, 112-121. [CrossRef]

19. Moran, M.J. Availability Analysis: A Guide to Efficient Energy Use, Revised Edition; American Society of Mechanical Engineers: New York, NY, USA, 1989.

20. Moran, M.J.; Sciubba, E. Exergy analysis: Principles and practice. J. Eng. Gas Turbines Power 1994, 116, 285-290. [CrossRef]

21. Szargut, J.; Morris, D.R.; Steward, F.R. Exergy Analysis of Thermal, Chemical and Metallurgical Processes; Hemisphere: New York, NY, USA, 1988.

22. Szargut, J. International progress in second law analysis. Energy 1980, 5, 709-718. [CrossRef]

23. Edgerton, R.H. Available Energy and Environmental Economics; D.C. Heath: Toronto, ON, Canada, 1992.

24. Dincer, I.; Rosen, M.A. Exergy: Energy, Environment and Sustainable Development; Elsevier: Oxford, UK, 2007.

25. Sato, N. Chemical Energy and Exergy: An Introduction to Chemical Thermodynamics for Engineers; Elsevier: Oxford, UK, 2005.

26. Caliskan, H. Novel approaches to exergy and economy based enhanced environmental analyses for energy systems. Energy Convers. Manag. 2015, 89, 156-161. [CrossRef]

27. Balkan, F.; Colak, N.; Hepbasli, A. Performance evaluation of a triple-effect evaporator with forward feed using exergy analysis. Int. J. Energy Res. 2005, 29, 455-470. [CrossRef]

28. Cornelissen, R.L. Thermodynamics and Sustainable Development: The Use of Exergy Analysis and the Reduction of Irreversibility. Ph.D. Thesis, University of Twente, Enschede, The Netherlands, 1997.

29. Van Gool, W. Energy Policy: Fairly Tales and Factualities. In Innovation and Technology-Strategies and Policies; Soares, O.D.D., da Cruz, A.M., Pereira, G.C., Soares, I.M.R.T., Reis, A.J.P.S., Eds.; Kluwer: Dordrecht, The Netherlands, 1997; pp. 93-105.

30. Hammond, G.P.; Stapleton, A.J. Exergy Analysis of the United Kingdom Energy System. Proc. Inst. Mech. Eng. Part A J. Power Energy 2001, 215, 141-162. [CrossRef]

31. Koroneos, C.; Spachos, T.; Mousiopoulos, N. Exergy analysis of renewable energy sources. Renew. Energy 2003, 28, 295-310. [CrossRef]

32. Wall, G. Exergetics; Exergy Ecology Democracy: Molndal, Sweden, 1998.

33. Amos, W.A. Costs of Storing and Transporting Hydrogen; National Renewable Energy Laboratory: Golden, CO, USA, 1998.

34. Beccali, G.; Cellura, M.; Mistretta, M. New exergy criterion in the multi-criteria context: A life cycle assessment of two plaster products. Energy Convers. Manag. 2003, 44, 2821-2838. [CrossRef]

35. Siemens Solar Panel. Available online: http://www.siemen.co.uk/sm55_sm50.html (accessed on 9 February 2017). 
36. The Wind Power. Available online: http://www.thewindpower.net/turbine_en_162_fuhrlander_100.php (accessed on 9 February 2017).

37. Ballard Power Systems. NexaTM Power Module User's Manual; Ballard Power Systems: Burnaby, BC, Canada, 2003.

38. Ballard Power Systems. Available online: www.ballard.com (accessed on 9 February 2017).

39. Norsk Hydro Electrolysers. Available online: http://www.nel-hydrogen.com/ (accessed on 1 November 2015).

40. Dewulf, J.; van Langenhove, H.; Mulder, J.; van den Berg, M.M.D.; van der Kooi, H.J.; de Swaan Arons, J. Illustrations towards quantifying the sustainability of technology. Green Chem. 2000, 2, 108-114. [CrossRef]

41. Rosen, M.A. Energy and exergy analyses of electrolytic hydrogen production. Int. J. Hydrogen. Energy 1995, 20, 547-553. [CrossRef]

42. Roland Berger GmbH. Fuel Cell Electric Buses_Potential For Sustainable Public Transport in Europe; The Fuel Cells and Hydrogen Joint Undertaking: München, Germany, 2016.

43. Ballard. Fuel Cell Electric Buses: An Attractive Value Proposition for Zero-Emission Buses in the United Kingdom; Ballard: Burnaby, BC, Canada, 2016.

(C) 2017 by the authors; licensee MDPI, Basel, Switzerland. This article is an open access article distributed under the terms and conditions of the Creative Commons Attribution (CC BY) license (http://creativecommons.org/licenses/by/4.0/). 